\title{
The Postcolonial Paradox of Eastern Agency
}

\author{
John M. HOBSON*
}

\section{Abstract}

Much of the postcolonial/non-Eurocentric literature that has emerged in recent years has concluded that the key antidote to Eurocentrism lies with the need to factor Eastern agency into our theoretical and empirical understandings/ explanations of world politics/economics. While I certainly endorse this proposition, we need, however, to be aware that Eastern agency is already a factor in much, though not all, of Eurocentric international theory. Hence we confront the "postcolonial paradox of Eastern agency"- that while the perceived postcoloniall non-Eurocentric antidote to Eurocentrism/ Orientalism is to "bring Eastern agency in" nevertheless it turns out that it was there in some form or another within international theory all along. This article reveals the different forms that Eastern agency takes within different variants of Eurocentric international theory while simultaneously opening up this concept to its multiple variants, thereby taking us beyond Edward Said's monolithic conception of Orientalism that he bequeathed to postcolonialism.

\section{Key Words}

Eurocentrism, agency, postcolonial paradox, Orientalism.

* Professor of Politics and International Relations, University of Sheffield.

\section{Introduction}

The development of postcolonial/ non-Eurocentric challenges to Western international theory has gained rapid pace within IR studies since the late 1990s. These developments have revealed the Eurocentric foundations of international/IPE theory, ${ }^{1}$ while also developing empirical accounts and explanations of the rise and development of the international system/world economy. ${ }^{2}$ One of the posited antidotes to Eurocentrism that has emerged from this growing literature is the need to factor in the role of Eastern agency into our empirical accounts and theories of world politics/economics. This derives from the unreflexively held postcolonial axiom, derived from Edward Said, ${ }^{3}$ that Eurocentrism/Orientalism reifies the West by granting it exclusive agency in the world while denying the existence of Eastern agency pretty much outright. Moreover, it is assumed that Eurocentrism dictates that imperialism is the only means by which the inferior races can and must be brought into civilised modernity. However, on much 
closer inspection it turns out, I shall argue, that Eurocentric international theory offers a wide spectrum of positions in these matters, ranging from awarding Eastern peoples/societies very low levels of agency to moderate and even high or very high levels, all of which are framed within different normative conceptions of imperialism and antiimperialism. Accordingly, this means that we need to be much more careful when treating Eastern agency as the antidote to Eurocentrism. This is not to say that Eastern agency is unimportant, for I believe that it is a crucial part of the antidote. But it is to say that we need to be much more precise when conceptualising its place within nonEurocentric theory. Hence the paradox of Eastern agency: that the perceived postcolonial/non-Eurocentric antidote to Eurocentrism/Orientalism is to "bring Eastern agency in" when it turns out that it was there in some form or another within international theory all along.

This more nuanced reading of Eurocentrism emerges when we unpack Said's highly reductive and monolithic conception of Orientalism. A key part of this paper's mandate, therefore, is to unpack the black box of Eurocentrism/ Orientalism in order to reveal its key constituent discourses. This article's argument is developed in three sections. Section one sketches as briefly as possible the various dimensions and component parts of Orientalism. The second section then sketches the various positions with regards to Eastern agency in the racistimperialist and racist anti-imperialist literature while the third does the same for the imperialist and anti-imperialist Eurocentric institutionalist literature.

\section{Unpacking and Re-visioning Orientalism}

To counter what I view as Said's doublereductive move I begin by breaking down his concept of Orientalism into two component parts- scientific racism and Eurocentric institutionalism- and then sub-dividing these categories into their imperialist and anti-imperialist components (see Table 1).

\section{Table 1: The four variants of generic Eurocentrism/Orientalism in international theory}

\begin{tabular}{|l|l|l|} 
& Pro-imperialist & Anti-imperialist \\
\hline $\begin{array}{l}\text { Eurocentric } \\
\text { Institutionalism }\end{array}$ & (A) Paternalist & (B) Anti-paternalist \\
\hline $\begin{array}{l}\text { Scientific } \\
\text { Racism }\end{array}$ & (C) Offensive & (D) Defensive \\
\hline
\end{tabular}


Much of the postcolonial/ non-Eurocentric literature that has emerged in recent years has concluded that the key antidote to Eurocentrism lies with the need to factor Eastern agency into our theoretical and empirical understandings/ explanations of world politics/ economics.

In essence, Eurocentric institutionalism locates difference to the degree of rationality found within a society's institutions and culture. The West is proclaimed superior because it has supposedly rational institutions, while the East's inferiority is presented as a function of its alleged irrational institutions. Thus while the West has for the last three centuries allegedly enjoyed civilised democracy/ liberalis $\mathrm{m} / \mathrm{individualis} \mathrm{m} / \mathrm{science}$, conversely, the East is said to have endured or suffered barbaric Oriental despotism, or simply the savage state of nature alongside authoritarianism/ collectivism/mysticism. By contrast, scientific racism places a strong degree of emphasis on genetics and biology as elements underpinning difference while often emphasising the role of climate and physical environment. For some, the causal pendulum of race behaviour swings towards the climaticl environmental pole, whereas for others it swings more towards the genetic pole. This multivalent archipelago of discourses was far more heterogeneous than Eurocentric institutionalism and was fractured into all sorts of subdiscourses, including Social Darwinism, Eugenics, Weismann's germ plasm theory, Mendelianism and, not least, Lamarckianism, some of which were complementary while others conflicted.

A crucial complicating factor of note here is that some variants of scientific racism, specifically Lamarckianism, factored social behaviour/practice into the mix alongside environment and climate when analysing race behaviour. This is important to note in the context of the argument of this article because social practice is also a fundamental property of Eurocentric institutionalism. Not surprisingly, this feature sometimes means that Lamarckian international thinkers and theorists have produced analyses and political visions that are very similar to those offered by various Eurocentric institutionalists. J.A. Hobson's paternalist Eurocentric vision of imperialism, for example, bears many striking similarities with the Lamarckian vision advanced by Paul Reinsch, as I will show later. More generally, this means that at times the borderline between scientific racism and Eurocentric institutionalism is blurred or fuzzy. 
Table 2 differentiates my reading from that of Said's. I have included all the key dimensions, the sum of which is that the relationship between scientific racism/Eurocentric institutionalism and the various dimensions concerning imperialism, Eastern agency and Western triumphalism are much more contingent in my reading than what is found in Said's.

Table 2: Alternative conceptions of Orientalism/Eurocentrism

\begin{tabular}{|c|c|c|}
\hline & $\begin{array}{l}\text { Said's reductive conception of } \\
\text { Orientalism }\end{array}$ & $\begin{array}{l}\text { "Non-reductive" conception of } \\
\text { Eurocentric institutionalism \& } \\
\text { scientific racism }\end{array}$ \\
\hline $\begin{array}{l}\text { Relationship of } \\
\text { Orientalism and } \\
\text { scientific racism }\end{array}$ & $\begin{array}{l}\text { Inherent } \\
\text { Racism, especially social } \\
\text { Darwinism and Eugenics, is } \\
\text { merely the highest expression of } \\
\text { imperialist-Orientalism }\end{array}$ & $\begin{array}{l}\text { Contingent } \\
\text { Racism and Eurocentric } \\
\text { institutionalism are analytically } \\
\text { differentiated even if at times } \\
\text { they share various overlaps }\end{array}$ \\
\hline $\begin{array}{l}\text { The centrality of } \\
\text { the "standard of } \\
\text { civilisation" }\end{array}$ & Yes & Yes \\
\hline $\begin{array}{l}\text { Agency is the } \\
\text { monopoly of the West }\end{array}$ & $\begin{array}{l}\text { Inherent } \\
\text { The West has hyper-agency, the East } \\
\text { has none }\end{array}$ & $\begin{array}{l}\text { Contingent } \\
\text { The West always has pioneering } \\
\text { agency, while the East ranges } \\
\text { from high to low levels of agency; } \\
\text { but where these are high they are } \\
\text { deemed to be regressive or barbaric }\end{array}$ \\
\hline $\begin{array}{l}\text { Propensity for } \\
\text { imperialism }\end{array}$ & Inherent & $\begin{array}{l}\text { Contingent } \\
\text { Can be imperialist and anti- } \\
\text { imperialist }\end{array}$ \\
\hline $\begin{array}{l}\text { Sensibility: } \\
\text { Propensity for } \\
\text { Western } \\
\text { triumphalism }\end{array}$ & Inherent & $\begin{array}{l}\text { Contingent } \\
\text { Racism is often highly defensive } \\
\text { and reflects Western anxiety. } \\
\text { Some racist thought and much } \\
\text { of Eurocentric institutionalism } \\
\text { exhibits Western self-confidence, } \\
\text { if not triumphalism }\end{array}$ \\
\hline
\end{tabular}

The focus in this article will be revealing the ontological place of Eastern agency found within the four key metanarratives that usually go under the generic term of Orientalism. I extract these from the international theory literature in the 
West since 1760. Because post-1945 international theory takes only various Eurocentric institutional guises, I shall begin by providing a highly condensed discussion of pre-1945 scientific racism.

\section{Eastern Agency within Anti- imperialist Scientific Racist International Theory,$$
\text { 1850-1945 }
$$

Here we encounter a spectrum of positions with respect to the place that Eastern agency occupies within antiimperialist racist thought. There are three broad positions situated along a continuum. At the far left-hand side lies those racists who denied Eastern races agency altogether. Here we encounter the likes of David Starr Jordan (in his pre1919 works) and James Blair. They argue that the non-white races are incapable of auto-generating and are therefore mired in regressive backwardness and stasis. In this vision the civilising mission is deemed pointless given that these races are incapable of being uplifted; to wit Blair's claim that "history shows no instance of a tropical people who have demonstrated a capacity for maintaining an enduring form of Republican government". ${ }^{4}$ Or as Jordan put it, "the race problem of the tropics are perennial and insoluble, for free institutions cannot exist where free men cannot live. The territorial (imperialist) expansion now contemplated (by the US government) would not extend our institutions, because the proposed colonies are incapable of self-government". 5 And Jordan presents a series of arguments that amount to the conclusion that empire is not worth the candle because it will serve ultimately to harm the colonial power and do nothing to help the inferior races abroad.

The West is proclaimed superior because it has supposedly rational institutions, while the East's inferiority is presented as a function of its alleged irrational institutions.

Moving rightwards to the mid-point of our continuum we encounter the likes of Herbert Spencer and William Graham Sumner who awarded the Eastern races a higher, albeit "moderate", amount of agency. Spencer asserted that all races are capable of auto-generation even if somenamely the black races- would take a very long time, possibly centuries, before they would break through to modernity. As Spencer put it:

The ultimate development of the ideal man is logically certain- as certain as any conclusion in which we place the most implicit faith; for instance that all men will die.... Progress, therefore, is not an accident, but a necessity. Instead of civilization being artificial, it is a part of nature [and is therefore open to all races]. ${ }^{6}$ 
Spencer in effect grants the Eastern races what I call "derivative agency", insofar as he believes that they will autogenerate into civilised modernity but only by following the "natural" path that had been pioneered by the trail-blazing Europeans.

Where Eastern agency is denied outright, lies a range of racists who embraced differing configurations of social Darwinism, Eugenics and Lamarckianism.

Spencer and Sumner also insisted that imperialism was dangerous both for coloniser- and colonised-societies. Spencer revelled in pointing out the hypocrisy of those left-wing racistimperialists who criticised his own laissez-faire political economy as callous while in the next breath

\begin{abstract}
you may hear them, with utter disregard of bloodshed and death, contend that it is in the interests of humanity at large that the inferior races should be exterminated and their places occupied by the superior races.... Not worthy of much respect then, as it seems to me, is this generous consideration of the inferior at home which is accompanied by the unscrupulous sacrifice of the inferior abroad. ${ }^{7}$
\end{abstract}

Moreover, while imperialism would hinder the non-white races equally it would lead to the "rebarbarisation of (white) civilisation", thereby causing a regression of Western civilisation into the more backward and coercive "militant society". ${ }^{8}$

Finally, a third major strand of antiimperialist racism can be found in the genre that is represented by the likes of Charles Henry Pearson and Lothrop Stoddard. ${ }^{9}$ Here the Eastern racesspecifically the yellow races of Japan and China as well as the Islamic brown races which are also singled out by Stoddardare granted very high levels of agency. While they view these races as capable of modernising this goes hand-in-hand with the negative trope of what I call Eastern "predatory agency" for they view the rapidly developing yellow and brown races as posing a significant threat to white civilisation in particular and to world order more generally. Both writers were extremely concerned by the Yellow/ Brown Peril which batters the walls of the Western citadel. Their posited solution for the West is to retreat from empire- for the most part- and to batten down the hatches of the Western citadel as these predatory races lay siege to civilisation and white racial supremacy. Colonising the yellow and brown races led only to negative blowback for the West, while Pearson, and many other racists for that matter, viewed the colonisation of the tropics as pointless owing to the degenerative impact of the sun's actinic rays on the white race. 


\section{Eastern Agency within} Imperialist Scientific Racist International Theory, 18501945

Here again we encounter a continuum or spectrum of positions ranging from very low levels of Eastern agency to moderate and sometimes high levels. With regards to the latter position we encounter the likes of Alfred Mahan and Halford Mackinder. In Mackinder's 1904 article and Mahan's 1897 book we encounter the trope of "predatory" Eastern agency. ${ }^{10}$ Both these authors convene the notion of the Yellow Peril, viewing the Chinese and Japanese as future threats to white racial supremacy. Unlike Stoddard and especially Pearson, however, their political response was to advance the cause of white racial imperialism as the means to counter and contain such a potential threat.

At the other extreme, where Eastern agency is denied outright, lies a range of racists who embraced differing configurations of social Darwinism, Eugenics and Lamarckianism. The likes of Theodore Roosevelt, Benjamin Kidd and Winwood Reade believed, like many Social Darwinists, that the agency-less non-white races were destined simply to die out upon contact with the white races since they were incapable of adapting to civilised life conditions. ${ }^{11}$ I call this the "indirect racial exterminist" brand of racist-imperialism. Others argued for a "direct racial exterminism" through which the white races would renew their racial vitality by conquering the non-white races and actively destroying them- either through breeding them out of existence ${ }^{12}$ or by wiping them out with the gun. ${ }^{13}$ And others too believed that the absence of Eastern agency meant that the white race was destined to spread and dominate the world. ${ }^{14}$

While Marx approved of imperialism as the only means by which the Eastern societies could be released from their self-imposed stagnation, he was insistent that imperialism was lamentable in a moral sense.

Finally, the mid-point position can be found in the likes of Paul Reinsch, Alleyne Ireland and Henry Sidgwick. ${ }^{15}$ They paralleled the paternalist Eurocentrics, arguing in effect that the non-white races were imbued with "conditional agency", such that they could develop but only on condition that the white race colonises them first and delivers the required rational institutions via the civilising mission. But while their political stances were very similar to those of the paternalist Eurocentrics the difference hinged on the particular metanarrative that underpinned their analyses. Thus, for example, while the theories of Hobson and Reinsch were 
very similar, nevertheless the latter's advocacy of an empathic imperialism rested on the belief that Eastern progress is a function of the passing on of rational modes of behaviour that are delivered by the West through the civilising mission, which are then absorbed and passed on within the Eastern races through hereditary characteristics to subsequent generations. Hobson, however, believed that the passing on of rational institutions from the West enables Eastern peoples to undo the blockages not in their minds but in their irrational societal and political institutions. To understand this I now turn to consider the Eurocentric institutionalist literature, and because it has dominated since 1945 I shall spend rather more time considering it.

\section{Eastern Agency within Imperialist Eurocentric Institutionalist International Theory}

Imperialist Eurocentrism embodies a strong dose of paternalism, which awards Western societies a pioneering agency such that they can auto-generate or auto-develop through what I call the "Eurocentric logic of immanence" into modernity, while conversely Eastern societies are granted conditional agency and are unable to auto-generate or selfdevelop. That is, Europe's exceptional institutional and cultural genius means that development into modernity was immanent from the outset (ie., from ancient Greece onwards) and that the story of Europe's breakthrough into capitalist modernity was foretold or preordained- it was but an historical fait accompli or rite of passage. Conversely, within this discourse Eastern peoples are deemed to have a latent rationality such that full rationality was blocked from reaching the surface on account of the existence of their irrational institutions. Accordingly, their societies were blocked from developing and they were destined to languish in stagnation at worst (as in savage anarchic societies) or at best they would be caught within a kind of highlevel agrarian equilibrium trap (as in some barbaric societies).

But there is a solution at hand. For in this paternalist imaginary it is incumbent upon the West to engage in an imperial civilising mission in order to deliver the necessary rational institutions to the Eastern societies so as to bring to the surface their latent reason, thereby kickstarting their progressive development into modernity- otherwise known as the "white man's burden". Thus once the necessary institutions have been delivered so Eastern peoples and societies are deemed sufficiently capable and rational to develop autonomously thereafter. In this discourse Eastern peoples are awarded 'conditional agency' in that they can develop but only on condition that the West intervenes first through the civilising mission. This form of Eastern agency is higher than that awarded by 
those racists who denied the Eastern peoples any agency whatsoever, though obviously far lower to the levels of agency that are awarded to the Europeans.

One point of note is that there was a range of positions regarding the precise modus operandi of the civilising mission. Indeed, their conceptions of imperialismas-a-civilising mission can be arranged along a continuum. At the far left-hand side of the continuum we encounter the likes of John Stuart Mill and Karl Marx, both of whom argued that imperialism should take a harsh, coercive form and that this was the only way that rational institutions could be delivered so as to kick-start Eastern development. ${ }^{16}$ Nevertheless, while Marx approved of imperialism as the only means by which the Eastern societies could be released from their self-imposed stagnation, he was insistent that imperialism was lamentable in a moral sense. As he put it forcefully in the first volume of Capital, and not without a considerable degree of sarcasm:

The discovery of gold and silver in America, the extirpation, enslavement and entombment in mines of the aboriginal population, the beginning of the conquest and looting of the East Indies, the turning of Africa into a warren for the commercial hunting of black-skins, signalised the rosy dawn of the era of capitalist production. These idyllic proceedings are the chief moments of primitive accumulation. ${ }^{17}$

At the other extreme situated at the far right-hand point of the continuum we encounter a series of thinkers who argued for a much more "empathic" brand of imperialism; and one that was often tied in with what might be called "international government". This was first mooted by J.A. Hobson in the second part of his famous text, Imperialism: A Study. ${ }^{18}$ Hobson believed that the solution to the exploitative form of empire, or what he called "insane imperialism", could be remedied not simply by income redistribution within the coloniser society but through what he called "sane imperialism" wherein national imperialisms would be supervised by an international government to ensure that the rights of the natives within the colonies would be upheld and that these peoples would be treated fairly and with dignity. This became the blue-print for inter-war paternalist Eurocentrism, which also embraced, in effect, the trope of conditional Eastern agency. ${ }^{19}$

Finally there is a range of thinkers who wrote before 1914 who are situated at the mid-point of the continuum. Surprisingly, some of them are conventionally associated with the cause of non-interventionism and anti-imperialism: Richard Cobden, John Bright and Norman Angell. ${ }^{20}$ Perhaps it is here where my reading will find resistance, possibly by various historians of Cobden. Thus it is important to note my conclusion: that Cobden's writings were politically schizophrenic. For there is no doubting the point that he spent much time criticising empire and all manner of quotes could be marshalled in this respect. But he also advanced a clear paternalistEurocentric analysis that is found on 
no less than 443 of the 991 pages in his posthumously published two-volume set, Political Writings. And it seems curious to say the least that some historians who have spent many years of their lives studying Cobden have seemingly failed to come across these crucial writings. Intersecting these two radically different interpretations of Cobden is the issue of the Crimean War, where the conventional interpretation suggests that Cobden's stance was symptomatic of his noninterventionist credentials par excellence. But there is a clear paternalist-Eurocentric sensibility that led him to this conclusion. Turkey was not worth "saving" as its barbaric institutions- particularly its Oriental despotic state and its regressive Islamic religion- had laid waste to this "marvellous" country and its people. ${ }^{21}$ And from there Cobden delivers his paternalist-imperial message, declaring that

we have no hesitation in avowing it as our deliberate conviction that not merely Great Britain, but the entire civilized (i.e., Western) world, will have reason to congratulate itself, the moment when (Turkey) again falls beneath the sceptre of any other European power whatever. Ages must elapse before its favoured region will become... the seat and centre of commerce, civilization, and true religion; but the first step towards this consummation must be to convert Constantinople again into that which every lover of humanity and peace longs to behold it- the capital of a Christian (civilised) people. ${ }^{22}$

Thus Cobden positively endorsed a Russian colonial take-over of Turkey on the grounds that this Western civilising mission would yield considerable benefits not just to Turkey but also to Europe in general and to Britain in particular. ${ }^{23}$ And, in typical Eurocentric style, he concludes that Turkish (Eastern) society was "unchanging and stationary" whereas Russian (European) society was "progressing". ${ }^{24}$ Interestingly, John Bright, another so-called non-interventionist Cobdenite, counselled similarly:

We are building up our Eastern Policy
on a false foundation- namely on the
perpetual maintenance of the most
immoral and filthy of all despotisms
over one of the fairest portions of the
earth which it has desolated, and over a
population it has degraded but has not
been able to destroy.

Smith and Kant both believed that all societies and peoples would traverse the different stages of development of their own accord, thereby implicitly negating the need for a civilising mission that for paternalist Eurocentrics is deemed to be a vital pre-requisite for Eastern development.

In the post-1945 era many IR theories embrace paternalist Eurocentrism. The classical pluralist wing of the English School, for example, argued that the expansion of European international society in the $18^{\text {th }}$ and $19^{\text {th }}$ centuries 
and running down to the 1960s was a progressive movement which helped solve the problem of deviant Eastern backwardness. ${ }^{26}$ While neorealist hegemonic stability theory and Robert Keohane's neoliberal institutionalist perspective also rely on the formula of pioneering Western agency/conditional Eastern agency, ${ }^{27}$ this Eurocentric idiom has returned with a vengeance in the post-Cold War era mainly, though not exclusively, in the guise of liberal international theory. Indeed large swathes of liberal-inspired international theory have gone back to the future of the paternalist-Eurocentrism of the period between c.1830 and 1945 . The 1945-1989 era, dominated by the process of decolonisation and the "bad name" that Hitler had given the cause of racism, saw subliminal Eurocentrism oust scientific racism, whereby terms such as empire, civilisation, barbarism, savagery and white racial supremacy were dropped in favour of their whitewashed equivalences- hegemony, "modernity versus tradition" and "core versus periphery". But after 1989 the E-word came back- "empire" - as did the C-word- "civilisation". And with the Soviet Union gone by 1991 the way was open for the Messianic reassertion of Western civilisational pride across the world and the "new imperialism" whereby the Rest would gloriously be remade in the image of the West $;^{28}$ all of which was encased within the explicit or manifest Eurocentrism that had existed before 1945 . Moreover, much of this was repeated within a large literature that I call "Western realism". ${ }^{29}$

\section{Eastern Agency in Anti- Imperialist/Anti-paternalist Eurocentric Institutionalism}

Once again we encounter a range of positions in the wide anti-imperialist Eurocentric literature. In the liberal schema we encounter Immanuel Kant and Adam Smith who award higher levels of agency to Eastern societies than did their paternalist Eurocentric cousins. They argue that Eastern peoples have a moderate level of agency insofar as they are deemed to be capable of auto-generation. This plays into their stages model of development. Smith and Kant both believed that all societies and peoples would traverse the different stages of development of their own accord, thereby implicitly negating the need for a civilising mission that for paternalist Eurocentrics is deemed to be a vital prerequisite for Eastern development. In this way Smith awarded the East what can be called derivative agency, which is clearly more robust than the conditional agency awarded by the paternalist Eurocentrics. Important here is Smith's assumption that modern commercialism is congruent with (universal) human nature such that modern capitalism is immanent within the make-up of all societies, given his famous definition of human nature as "the propensity to truck, barter and exchange one thing 
for another". ${ }^{30}$ That is, all peoples would converge eventually on this stage of development since it was simply part of mankind's universal human nature.

But the Eurocentric giveaway lies in the point that for Smith and Kant all societies would converge upon a commercial society though they would only do so by following the "natural" path that had been trailblazed by the Europeans who are girded with "pioneering" agency. In these respects Smith and Kant overlap with the racist perspective of Spencer and Sumner that was discussed earlier. A further point of overlap with Spencerean racism lies in Smith and Kant's anti-imperialist arguments wherein intervention through imperialism would serve only to disturb in a negative fashion the developmental trajectory of both the colonised and coloniser countries. And they also abhorred the immorality and arrogance of Western imperialism, as did Spencer and Sumner. ${ }^{31}$ Nevertheless, they rejected the racist arguments that Spencer deployed.

Another anti-paternalist theory that critiques Western imperialism is found in numerous classical Marxist works (bar Marx and Engels). ${ }^{32}$ In this genre we encounter the idiom of an all powerful Leviathanesque-West that crushes the passive and inert East through imperialism, both in its formal and informal guises. Many readers might reason that a critique of the West would surely be congruent with an anti-Eurocentric approach. But I argue that it is perfectly possible to produce a critique of the West while maintaining a Eurocentric stance. In fact, in one crucial respect the classical Marxist approach is yet more Eurocentric than Smith and Kant's approach as well as the paternalist Eurocentric approach of the likes of Marx and Engels, Hobson and Angell. For this genre awards the lowest levels of Eastern agency found in the majority of the Eurocentric and scientific racist genres already discussed. Moreover, it is precisely this outright denial of Eastern agency that is reproduced in much of modern neo-Marxist work, found most clearly in the world-systems theory of Immanuel Wallerstein and others. ${ }^{33}$

Finally, the anti-imperialist theory of the "clash of civilisations", advanced by Samuel Huntington and William Lind, awards very high levels of agency to the Eastern peoples. ${ }^{34}$ This approach very much takes us back to the future of pre-1945 racist cultural-realism that was advanced by Stoddard, Pearson and others, though it is now dressed up in Eurocentric institutional clothing. Once again, Eastern agency is in effect viewed as "predatory" insofar as various Eastern peoples- mainly the Muslims and the Chinese- pose a threat to Western hegemony and supremacy. And once again, the posited solution is to avoid Western imperialist universalism and batten down the hatches of the Western citadel in order to maintain a pure Western identity within a multicultural world. 


\section{Endnotes}

1 See, for example, L.H.M. Ling, Postcolonial International Relations, Houndmills, Palgrave Macmillan, 2002; David L. Blaney and Naeem Inayatullah, Savage Economics, London, Routledge, 2010; John M. Hobson, The Eurocentric Conception of World Politics: Western International Theory, 1760-2010, Cambridge, Cambridge University Press, 2012; John M. Hobson, "Part 1- Revealing the Eurocentric Foundations of IPE: A Critical Historiography of the Discipline from the Classical to the Modern Era”, Review of International Political Economy, Vol. 20, No. 5 (2013), pp. 1024-1054.

2 See, for example, John M. Hobson, The Eastern Origins of Western Civilisation, Cambridge, Cambridge University Press, 2004; Shogo Suzuki, Yongjin Zhang and Joel Quirk (eds.), International Orders in Early Modern Europe, London, Routledge, 2013.

3 Edward W. Said, Orientalism, London, Penguin, 1978/2003.

4 James L. Blair, Imperialism, Our New National Policy, St. Louis, Gottschalk, 1899, p. 18.

5 David S. Jordan, Imperial Democracy, New York, D. Appleton \& Co., 1901, p. 44.

6 Herbert Spencer, Social Statics, New York, D. Appleton \& Co., 1851/1864, pp. 79-80.

7 Herbert Spencer, The Man Versus the State, London, Williams \& Norgate, 1881, p. 71. See also, Herbert Spencer, The Principles of Ethics, Vol. 2, Osnabrück, Otto Zeller, 1893/1966, pp. 257, 362.

8 Herbert Spencer, Facts and Comments, New York, D. Appleton and Co., 1902, pp. 157-200.

9 Lothrop Stoddard, The Rising Tide of Color Against White World Supremacy, New York, Charles Scribner's Sons, 1920; Charles H. Pearson, National Life and Character: A Forecast, London, Macmillan, 1894.

10 Halford J. Mackinder, "The Geographical Pivot of History”, The Geographical Journal, Vol. 23, No. 4 (1904), pp. 421-37; Alfred T. Mahan, The Influence of Seapower upon History, London, Sampson, Law, Marston, 1897.

11 Theodore Roosevelt, The Strenuous Life, New York, The Century Co., 1905; Benjamin Kidd, The Control of the Tropics, New York, Macmillan, 1898; William W. Reade, Savage Africa, New York, Harper \& Brothers, 1864.

12 Lester F. Ward, Pure Sociology, Honolulu, University Press of the Pacific, 1903/2002; Ludwig Gumplowicz, Der Rassenkampf, Innsbruck, Verlag der Wagner Schen Univ. Buchhandlung, 1883.

13 Karl Pearson, National Life from the Standpoint of Science, London, Adam \& Charles Black, 1905.

14 John R. Seeley, The Expansion of England, Leipzig, Velhagen \& Klansing, 1883/1906; Charles Dilke, Greater Britain, 2 Vols., London, Macmillan, 1868.

15 Paul S. Reinsch, Colonial Administration, New York, Macmillan, 1905; Alleyne Ireland, The Far Eastern Tropics, Boston, Houghton, Mifflin \& Co., 1905; Henry Sidgwick, The Elements of Politics, London, Macmillan, 1897.

16 John Stuart Mill, “A Few Words on Non-intervention”, in John M. Robson, Collected Works of John Stuart Mill, Vol. 21, Toronto, Toronto University Press, 1859/1984, p. 118. 
17 Karl Marx, Capital, Vol. I, London, Lawrence \& Wishart, 1867/1954, p. 703.

18 John A. Hobson, Imperialism: A Study, $3^{\text {rd }}$ edition, London, George Allen \& Unwin, 1938/1968.

19 Norman Angell, The Defence of the Empire, London, Hamish Hamilton, 1937; Alfred Zimmern, The Third British Empire, Oxford, Oxford University Press, 1934; Leonard Woolf, Empire and Commerce in Africa, London, George Allen \& Unwin, 1920; Leonard Woolf, Imperialism and Civilization, London, Hogarth Press, 1928/1933.

20 Richard Cobden, Political Writings, 2 vols., London, William Ridgway, 1868; John Bright, The Public Letters of the Right Hon. John Bright, edited by H.J. Leech, London, Sampson Low, Marston \& Co., 1895; Norman Angell, The Great Illusion, London, G.P. Putnam's Sons, 1913.

21 See for example, Cobden, Political Writings, Vol. 1, pp. 19, 173-174.

22 Cobden, Political Writings, Vol. 1, p. 33.

23 Ibid., pp. 33-37, 189-191.

24 Ibid., pp. 187-188.

25 Bright, Public Letters, p. 14.

26 Adam Watson, The Evolution of International Society, London, Routledge, 1992/2009; Hedley Bull, "The European International Order", in Kai Alderson and Andrew Hurrell, Hedley Bull on International Society, London, Palgrave Macmillan, 2000, pp. 170-187.

27 John M. Hobson, The Eurocentric Conception of World Politics, Cambridge, Cambridge University Press, 2012, pp. 193- 203, 216- 222.

28 See, for example, John Rawls, The Law of Peoples, London, Harvard University Press, 1999; David Rothkopf, "In Praise of Cultural Imperialism”, Foreign Policy, Vol. 107 (Summer 1997), pp. 38-53; Francis Fukuyama, The End of History and the Last Man, London, Hamish Hamilton, 1992; Robert Cooper, The Breaking of Nations, London, Atlantic Books, 2004; Michael Ignatieff, "Empire Lite”, Prospect, Vol. 83 (February 2003), at http://www.prospectmagazine. co.uk/2003/02/empirelite/ [last visited 22 January 2014].

29 Niall Ferguson, Colossus, Harmondsworth, Penguin, 2004; Zebigniew Brzezinski, The Choice, New York, Basic Books, 2004; Stephen D. Krasner, "Sharing Sovereignty: New Institutions for Collapsed and Failing States", International Security, Vol. 29, No. 2 (Fall 2004), pp. 85- 120; Robert Kagan, The Return of History and the End of Dreams, London, Atlantic Books, 2008.

30 Adam Smith, The Wealth of Nations, New York, The Modern Library, 1776/1937, p. 13.

31 Immanuel Kant, "Perpetual Peace: A Philosophical Sketch", and Kant, "The Metaphysics of Morals". Both are found in Hans Reiss (ed.), Kant's Political Writings, Cambridge, Cambridge University Press, 1970, pp. 93-130 and 131-75 respectively; Smith, Wealth of Nations, Book 4, Chapter 7. For a fuller discussion see Hobson, Eurocentric Conception, pp. 62- 66.

32 For example, Vladimir I. Lenin, Imperialism, the Highest Stage of Capitalism, Peking, Foreign Languages Press, 1916/1973; Rudolf Hilferding, Finance Capital, London, Routledge \& Kegan Paul, 1910/1985.

33 See, Hobson, Eurocentric Conception, Chapter 10.

34 Samuel P. Huntington, The Clash of Civilizations and the Remaking of World Order, London, Touchstone, 1996; William S. Lind, "Defending Western Culture", Foreign Policy, Vol. 84 (1991), pp. 40- 50. 